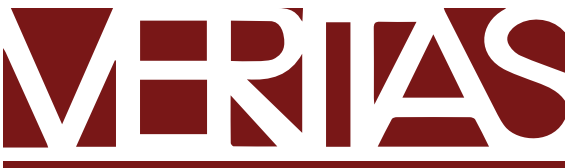

$\begin{array}{lllllllllll}P & O & R & T & O & A & L & E & G & R & E\end{array}$

http://dx.doi.org/10.15448/1984-6746.2019.2.33871

\title{
NOTES TOWARDS AN AESTHETICS OF THOUGHT ${ }^{1}$
}

\author{
Notas para uma estética do pensamento \\ Notas hacia una estética del pensamiento
}

Eduardo Luft ${ }^{2}$

Pontifícia Universidade Católica do Rio Grande do Sul (PUCRS), Porto Alegre, RS, Brasil

\begin{abstract}
Abstract: Based on the previous results of the immanent critique of Hegel's Logic that led to the system project of evolutionary idealism, the author seeks an aesthetics of thought prior to any theory of the beautiful, even if not without consequences for a future approach in this direction.
\end{abstract}

Keywords: Hegel, evolutionary idealism, dialectic, aesthetics.

\section{Resumo}

Pressupondo os resultados prévios da crítica interna à Lógica de Hegel que conduziram ao projeto de sistema do idealismo evolutivo, o autor busca por uma estética do

\footnotetext{
A first portuguese version of this paper can be found in E. Luft, 2014b.

2 Prof. Dr. Pontifícia Universidade Católica do Rio Grande do Sul (PUCRS). http://orcid. org/0000-0001-9935-9192. E-mail: eduardo.luft@pucrs.br
} 
pensamento anterior a qualquer teoria do belo, embora não sem conseqüências para uma futura abordagem neste sentido.

Palavras-chave: Hegel, idealismo evolutivo, dialética, estética.

\section{Resumen}

Suponiendo que los resultados anteriores de la crítica interna de la Lógica de Hegel que condujeron al proyecto de sistema del idealismo evolutivo, la búsqueda del autor se ubica en una del estética del pensamiento que precede a cualquier teoría de lo bello, aunque no sin consecuencias para el futuro enfoque en este sentido.

Palabras clave: Hegel, idealismo, dialéctica, estética.

1. The intuition for these notes came during a flight across the Atlantic, while reading Quentin Meillassoux's 'Iteration, Reiteration, Repetition'3. I realised that I have been approaching a theory of thinking from the opposite direction of Meillassoux's, exploring logical space in the vicinity of what I call Gorgias' Configuration ${ }^{4}$. Therefore, I don't depart from a form of thought that manifests itself mostly in determined conceptual networks, but from a theory of thought mostly manifested in the form of intuition (or of a thought built-in metaphors ${ }^{5}$, in almost pure images of thinking). I will thus try to renew a theory of intellectual intuition, though certainly not a theory of intellectual intuition as absolute knowledge.

2. The search for an aesthetics of thought prior to any theory of the beautiful, even if not without consequences for the latter, was initiated by Kant in the approach to aesthesis in his 'transcendental aesthetic'. But in Kant, we are not dealing with aesthetics of thought properly speaking if we remember that the Critique of Pure Reason strictly opposes the passive or

\footnotetext{
3 SEE MEILLASSOUX, 2012.

4 More on this later.

5 "There is no purely logical space which can be freed from all myths and metaphors as even the notion of 'logical space' obviously serves as a metaphor to delineate the 'boundless sphere' of rationality, to give us a picture in which we can recognize ourselves" (Gabriel, 2009, p.64).
} 
receptive (intuitive) faculty of sensibility, and the active or spontaneous (discursive) faculty of thought (broken down into understanding and reason). Kant, however, takes this contrast to such extremes that we can ask ourselves how it is at all possible that transcendental philosophy can have a theory of intuition - that is, how intuition can be rescued from the nothingness that this absolute contrast throws it into, how it can still be brought under the concept. 'In the transcendental aesthetic, we shall first isolate sensibility, purifying it from everything that thought thinks according to its concepts, so that the only thing left is empirical intuition'. ${ }^{6}$

3. But what is really left? For Kant, on the one hand, we would have the pure forms of space and time that guarantee the 'apodictic certainty' of geometry and arithmetic; on the other, the matter of sensibility, devoid of all conceptual determination, that is, the pure indeterminacy of the thing-in-itself. As for the first residual trace of intuition resulting from that absolute opposition, we could insist, contra Kant, that the alleged 'pure forms of intuition' are no more than discursive modes of thought lacking in 'absolute unity' or 'apodictic certainty' that could free them from the mediation of the concept, which becomes evident with the diversity of geometries and possible conceptions of time or space-time available to contemporary thought. The attempts to reconstruct intuition as a kind of immediate knowledge which, for exactly that reason, would secure apodictic certainty - being it in the form of the immediacy of sensible intuition (empiricism and dogmatic transcendentalism) or intellectual intuition (dogmatic rationalism) - thus seem condemned to flounder, since any attempt to conceive intuition as external and prior to the mediating power of the concept must, in fact, presuppose the latter (something that can be derived, as we shall see, from the thesis of the 'unboundedness of the conceptual').

4. The second residual trace is far more interesting. The fact that what is left of intuition is only the paradox of a non-concept or of an 'in-

6 KANT, KRV, B36. 
determinate object' - 'the indeterminate object of an empirical intuition is called phenomenon' 7 - says all we need to hear about the bias towards the One $e^{8}$ that pervades transcendental philosophy. Kant not only started out from that absolute contrast between intuition and thought, but went as far as defining the latter as the act of 'uniting representations under a consciousness' 9 , at the same time as he conceived such unity under the determinant form of judgment. To the paradoxical indeterminacy of intuition 'left alone' is opposed the full determinacy of thought. If we add to this the fact that thought, in its synthetic acts, is conceived as systematic thought in principle, a discourse that is oriented by the idea of determinate totalisation or completeness, it will become evident that everything in transcendental philosophy derives from that initial absolute opposition. As a matter of fact, not only is all that falls under thought determined according to the logical structure of judgement, but every act of judgment is oriented towards 'complete determination' (durchgängige Bestimmung) ${ }^{10}$. Thus, for Kant, when what is at stake is securing the criticality of transcendental philosophy, everything hinges on the idea that a complete totality can only be thought and never known, that is, everything depends on that absolute contrast set at the start that prevents the spontaneity of thought to become free from the receptivity of intuition. Disconnected from the determining power of the concept, intuition would be thrust into the 'determination void' of the pure matter of sensibility, as much as the world of phenomena would be thrown into the void without the ordering presence of ideas according to the classic reading of Plato. Disconnected from the indeterminate power of intuition, the concept would take off straight into a complete and achieved system of pure reason, which is to say, we would be back at the dogma of pre-critical metaphysics. But the

\footnotetext{
7 KANT, KrV, B34.

8 LUFT, 2014 a.

9 KANT, Prol, §22.

10 KANT, KrV, B604.
} 
essential question that remains unanswered is: what guarantees this very connection, what is the thread that could connect the indeterminacy of intuition to the determinacy of the concept?

5. This is the theoretical context in which Hegel's work appears, especially his Science of Logic, an immanent critique of which gives rise to the theory of dynamic logical space that I have in mind here. This moves us into the search for an aesthetics of thought. In Hegel's Logic the paradox referred to in the previous note is taken to its extreme form. From it is derived the ambiguous structure of the book, which can at once be read as a meta-logic that radicalizes the criticality of transcendental philosophy and as a hyperlogic that aims to accomplish that ideal of completeness" ${ }^{11}$.

6. Let us remember that the 'founding' act of Hegel's Logic is the demolition of 'ground', that is, its starting point is the refusal of any postulate accepted prior to the autocritical activity of thought. The Logic starts not with an act of determination, but with an act of freedom from determinacy, a 'letting be-there' of purely indeterminate being which, for that reason precisely, can be regarded as 'this pure, empty intuition'.12 The Logic 'must presuppose nothing'13, not even the laws of judicative (propositional, in today's parlance) discourse, which is in fact only established or dialectically reconstructed at the end of the work.

7. The Hegelian manouevre will ensure the enhancement and radicalisation of the critical enterprise inherited, above all, from Descartes and Kant. The proposal of a metacritique to Kant's Critique of Pure Reason is tied to the Hegelian critique of what I have elsewhere referred to as the "myth of the referential framework in logic"14. Transcendental philosophy found support in the dogma of the unreflected presupposition of the formal structures of classic logic. Freedom from this dogma enables, on the one

\footnotetext{
1 LUFT, 2015.

$12 \mathrm{WL}, 5, \mathrm{p} .82$.

$13 \quad W L, 5$, p.69.

14 LUFT, 2015, p.57.
} 
hand, a deepening of critical activity and, on the other, a widening of the scope of sense into until then unsuspected areas. In the critical-reflexive search for the universal principle of intelligibility, Hegel's Logic - built, like all of his great works, backwards - finds sense way beyond propositional discourse. The terms with which the book begins - 'being', 'nothing', 'becoming' -, mere concepts disconnected from any propositional articulations, show the way. Even if all determination of sense involves relation and, strictly speaking, every sense can only take place within semantic networks or configurations and not in isolated forms (something Hegel wishes to demonstrate from the very first steps of his Logic), this does not imply the demand that the articulation of concepts necessarily take propositional form. From this comes the first central idea I will explore in this essay: that it is necessary to allow unheard-of modes of expression that lie way above or below propositional structure to emerge.

8. Yet there are two deficits in Hegel's approach. First, it is never explained how that act of 'freedom from determination' with which the Logic begins could still be an act of thought; he never presented a theory of how indetermination is even thinkable. As we shall see later, my thesis is that indetermination is indeed unthinkable or unintelligible, but a 'beyond' of determination is nonetheless thinkable in the form of underdetermination.

9. Secondly, the bias towards the One is not only preserved in its entirety but, in a certain way, deepened, insofar as the dialectical movement of the Concept is anchored by a teleology of the unconditioned's. If the Doctrine of Being and the Doctrine of Essence can be considered the core of Hegel's metalogic as critical radicalisation, that is, privileged moments in the dissolution of classic metaphysics ${ }^{16}$ (critique of the classic theories of being, substance, and essentialism), the Doctrine of the Concept seeks to actualize the Kantian ideal of complete determination of thought in a system of pure reason. All previous categories or thought

\footnotetext{
15 LUFT, 2015, p.52.

16 THEUNISSEN, 1994.
} 
determinations must be re-expressed at the end of the Logic as figures or moments in the semantic configuration of the concept (in the dialectics of the universal, particular and singular), for the concept to then be deployed in conceptual networks expressed in judgments (propositions, as we would say today) and, finally, judgments be re-expressed in networks of judgments or syllogisms (inferences, in today's parlance). In this way, the work that began in the extreme form of the void of determination of being will find its closure - when the syllogistic structure unfolds as objective and, finally, absolute structure - in the complete determination of the absolute idea. The Science of Logic ends in a paradox: dialectics, thus accomplished, dissolves itself ${ }^{17}$, and metalogic disappears into hyperlogic.

10. The way out of this impasse can be found in the radicalisation of the second movement of widening the sphere of sense carried out by Hegel, under the thesis that McDowell has renamed 'unboundedness of the conceptual'.18 We encounter the real scope of the sphere of sense when we become aware of the conceptual character of both modes of intuition, sensible and intellectual, mapped by tradition. Hegel discloses the conceptual nature of the first at the start of the Phenomenology of Spirit, when he deals with sensible certainty, and renders explicit the conceptual trace of the second in the beginning of the Science of Logic, as we have seen when he treats being as tantamount to 'empty intuition'. ${ }^{9}$ This allows for the overcoming of the seemingly insurmountable impasses of every dualistic conception of the relation between intuition and concept. On the contrary, we need to defend the idea that intuition and concept are not different in nature, but only in degree; what we call 'intuition' and 'concept' are no more than extreme manifestations of different degrees of determination of thought.

\footnotetext{
LUFT, 2001.

18 MCDOWELL, 1996.

$19 \mathrm{WL}, 5, \mathrm{p} .82$.
} 
11. We know, however, that Hegel did not bequeath us any theory of intuition properly speaking. If his philosophy expanded the limits of thought to somewhere below propositional form, it literally stopped at the edge of the intuitive, like a stubborn horse been facing an abyss. Hegel only ever got at intuition in negative ways; it was grasped in its process of dissolution only - the passing of the singularity of sensible intuition into the universality of the concept (Phenomenology), and of being as pure intuition into the Concept (Logic). It is necessary to go beyond, expanding the sphere of sense to the realm where the concept has no longer any predominance and intuition can rise to the surface.

12. To free dialectics from its paradoxical situation requires negating the teleology of the unconditioned, that is, the Hegelian thesis that the end of dialectical process and the moment that lead to it are predetermined by a specific configuration of thought - in this case, the Concept itself. We accept the minimum demand for coherence that is inherent to Hegelian philosophy as well as any philosophy that wishes to be dialectical ${ }^{20}$ ('only that which is coherent remains determinate ${ }^{21}$ ), but there are multiple, potentially infinite modes in which coherence can manifest itself. This third-order critique - that is, this curious critique to the Hegelian critique of Kantian critique - amounts to literally 'weighing anchor' of the sphere of sense, which entails three drastic consequences: a) the Hegelian theory of pure logical space - the core of objective idealism anchored to the dualism of ideality (Logic) and reality (Real Philosophy) - is unmade in a theory of dynamic logical space (evolutionary idealism); b) the Hegelian theory of Absolute Knowing and the dualism of Phenomenology of Spirit and Logic that derives from it is turned into a generalised fallibilism; and c) the inflationary

20 CIRNE-LIMA, 2006.

21 LUFT, 2014a, p. 961. 
ontology of the Concept is turned into the deflationary ontology of the idea of coherence ${ }^{22}$.

13. Here, I would like to contemplate only the consequences of this deflation of Hegelian logic for a theory of thought. 'Weighing anchor' in the sphere of sense entails allowing for the free exploration, by thought, of the vast field opened up by the theory of dynamic logical space, moving among all possible modes of the manifestation of sense, that is, all coherent modes of thought. Coherence is the unity of a multiplicity or a multiplicity in unity or updating platonic terminology 23 , the idea of coherence consists of the dialectic of the One and the Many. Let us associate to the One the notes of identity, invariance and determination and, to the Many, those of difference, variation, and underdetermination ${ }^{24}$. Then I would say: coherence can occur in multiple, potentially infinite ways: it manifests itself in the most determinate thought (in the vicinity of Parmenides' Configuration) and also in the less determinate one (in the vicinity of Gorgias' Configuration). The envelopment of all possible thoughts or beings in the idea of coherence is the dynamic logical space.

\footnotetext{
22 LUFT, 2014a, p.962.

23 LUFT, 2017.

24 As I pointed out elsewhere, "I strictly distinguish between "underdetermination" and "indetermination": underdetermination is the property of an event whose occurrence is only one among ' $n$ ' (definite or indefinite) possibilities in a limited field of possibilities of occurrence, considering the validity of a given principle of order; indetermination is the property of an event whose occurrence is only one among ' $n$ ' possibilities in an unlimited (unrestricted) field of possibilities of occurrence, considering the validity of a given principle of order. Now, an unrestricted field is no field at all; thus, there cannot be indetermination, but only underdetermination in the universe" (Luft, 2010, p.101).
} 


\section{Gráfico 1}

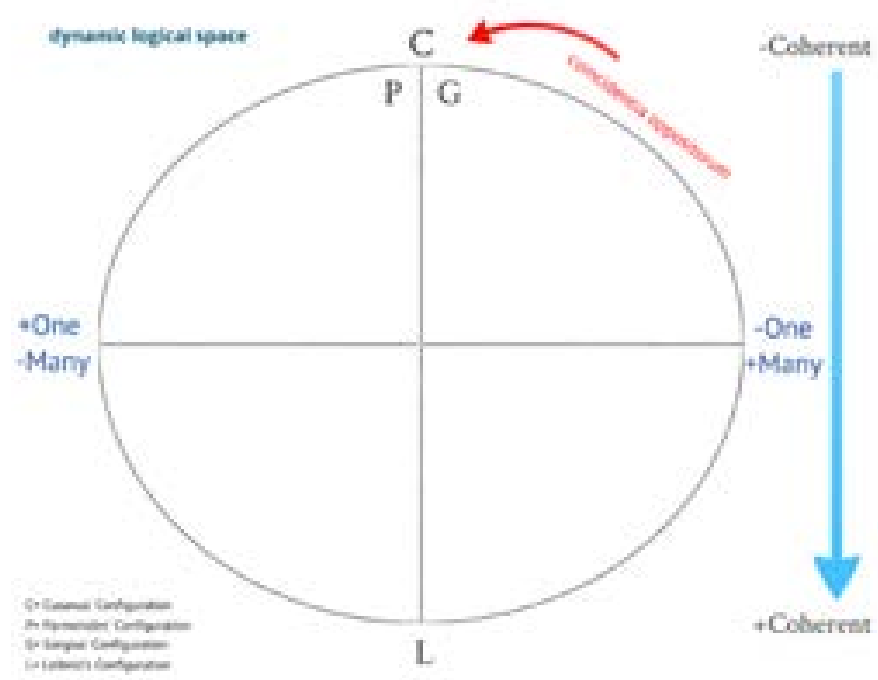

14. Against the bias towards the One bequeathed by tradition, we need to see coherence as manifesting itself not only there where maximum order is predominant (or borrowing the notation used in the context of metaphysics, in the vicinity of Parmenides' Configuration) ${ }^{25}$, but also, and

${ }_{25}$ In order to understand the Figure that follows: Each point in the traced line of the circumference corresponds to a possible configuration (the traced lines inside the circumference only serve to demarcate the quadrants). For this very reason, the figure is clearly a simplification, since there are potentially infinite possible configurations, and the number of points which form the circumference represented here is finite. The arrow pointing downwards on the right of the circumference indicates that the configurations situated in the lower semi-circumference, closer, therefore, to the Leibniz's Configuration $(L)$, are more coherent $(+C)$ with the dynamism of the universal becoming and can generate their own history. The Parmenides' Configuration (P) is actually the Cusanus' Configuration (C) itself "observed" from the perspective of someone who follows the circular movement which goes from right to left, thus beginning (near) the Gorgias' Configuration (G), passing by the Leibniz's Configuration and leading into the Parmenides' Configuration; the Gorgias' Configuration is the Cusanus' Configuration itself "seen" from the perspective of someone who follows the opposite movement, following the circular movement which goes from left to right, from the Parmenides' Configuration, passing by the Leibniz's Configuration and leading into the Gorgias' Configuration. 'Logical Space' is to be understood here in the logical-ontological sense: it is the space which, on the one hand, 
chiefly - so that the next steps in this essay can be followed - there were predominates maximum chaos, in the vicinity of Gorgias' Configuration.

15. That is, we need to learn to see coherence in a different way, mainly to see it in the second sense in which I now start to use the concept of intuition. This receptive moment of thought can be understood in two ways. We can conceive it as the crystallised form of the concept, as when we say that our thought 'is done', 'lies before us' and can be 'reproduced' or 'passed on'. It is exactly in this superficial sense that one speaks of 'sensible intuition', 'experience' or 'observation' in naïve empiricism, when in fact we are not dealing with intuition properly speaking, but the concept in its naturalised form, taken as 'natural interpretation' as Feyerabend would say. ${ }^{26}$ Also in this improper sense, we say that we 'intuit', for instance, basic mathematical notions in naïve rationalism.

16. But intuition can be understood in a less superficial and more proper sense: receptivity emerges in thought when the latter does not merely iterate a given configuration of thought - such as when we say that the molecular proposition like 'Socrates is mortal or is not mortal' is a necessary truth by iterating the primary configurations or 'laws' of bivalent logic. When we cease to merely iterate, when we 'weigh anchor' in thought, the latter opens up to possibilities other than those already anticipated, taking on a receptive attitude.

17. We need to look at coherence such as it manifests itself at the edges of Gorgias' Configuration but, before that, I would like to follow its deployment in less extreme forms of the predominance of the Many, in the vicinity of Leibniz's Configuration. As I mentioned before, intuition and concept should neither be understood as exclusive opposites associated to different faculties, such as sensibility and discourse, nor as different kinds of thought or discourse, with independent principles as their ground.

envelops all possible thoughts (= all possible forms of discourse), and on the other all possible forms of existence, presupposing the universal validity of the idea of coherence.

26 FEYERABEND, 1993, p. 54ff. 
Intuition and concept are only different degrees of the manifestation of sense in acts of thought. Now let us do the following thought experiment: let us imagine ourselves following the movement that goes from the vicinity of Parmenides' Configuration to Gorgias' Configuration. The moment when the concept begins its retreat and allows intuition to take over is in the passage through Leibniz's Configuration. The demarcation is given by the emergence of those configurations of thought that bring to the fore the predominance of the Many as first degree of potentiality, that is: thought is no longer iterative and allows, under the constraints of some presupposed configuration, other possibilities of sense to emerge, which are free even if previously delimited and defined as possibilities by that pre-established configuration, such as the horse's moves are predefined as possibilities by the rules of chess. That is, the semantic figures and configurations that emerge at each moment under that originary or background configuration are underdetermined by it.

18. Let us proceed in our journey to Gorgias' Configuration. The manifestation of the second degree of potentiality is the mark of the transition to the Gorgias' Quadrant (the first (upper-right) quadrant of the logical space): the sense-events that now emerge under the presupposed idea of coherence,are enveloped in and by it, i.e., they are not even predefined as possibilities under the originary constraint of the requirement of coherence. The idea of coherence only surrounds or envelops the possibilities, like the father who, trying to prevent his children and their friends from tearing the house down, circles sofas around the lounge and restricts their playspace, clearly delimiting their field of possible play without predefining the kinds of games that may take place within it.

19. Here, in the vicinity of Gorgias' Configuration, intuition shows its full force. Receptivity expresses, in its deepest sense, this openness of thought to non-predefined possibilities which are only enveloped by the requirement of coherence. We know that figures of sense do not emerge on their own, in isolation from other figures - since, given the idea of coherence, every determination presupposes relation. We also 
know that the conditioning ties among different figures cannot retreat into the infinite, and are only stabilised as moments of configurations of sense or semantic configurations. But nothing is said, in the vicinity of Gorgias' Configuration, of which semantic configurations will emerge in this or that act of thought.

20. So as to make this speculative study more tangible to the mathematics-inclined reader, we could seek an approximate formalisation of the dialectics of the One and the Many with the aid of concepts from network theory. The semantic networks that emerge in the second quadrant (upper-left) of dynamic logical space (in the vicinity of Parmenides' Configuration) could be formalised as regular networks; and those that emerge in the first (in the vicinity of Gorgias' Configuration) as random ones. I say 'approximate formalisation' because random networks do not really ascend from the fourth to the first quadrant, as they operate under the presupposition of predefined possibilities.

21. Instead, so as to render this study palatable to the poetry-inclined reader, the opposition between the semantic configurations that emerge in the vicinity of Parmenides' Configuration and those that emerge in the vicinity of Gorgias' Configuration could be grasped by the difference between the two following thoughts:

a) $p \vee \neg p$;

b) Mudas palavras:

de tanto calar, desmoronam ${ }^{27}$.

22. What differentiates logical and poetic thinking? Degrees of determinacy and the way in which, according to different degrees, intuition or

27 "Silent words:/By so much quietness/Tumble "(By the author). 
concept have the upper hand on each other. The first thought in the note above is a molecular proposition that expresses a necessary truth under the presupposition of the first configurations or 'laws' of bivalent logic, characterised by its iterative way and its closure. The second is a simple poem, whose defining traits are its openness to different interpretative possibilities. The first flirts with the concept, the second with intuition, but neither of them is pure concept or pure intuition, as all possible forms of thought contain the One and the Many as their complementary poles.

23. Even though it is capable of exploring the whole width of dynamic logical space, thought is more coherent with the very dynamism introduced by the pervasive presence of contingency in deflationary ontology when it manifests itself in the lower quadrants of the logical space ${ }^{28}$, i.e. in the vicinity of Leibniz's Configuration - that configuration which brings together 'the greatest variety under the greatest order'. ${ }^{29}$ That is, thought tends to manifest itself in a more coherent way neither in the extreme predominance of intuition, nor in the extreme predominance of the concept, but in the golden mean between the two: it tends towards Leibniz's Quadrants. The pervasive presence of scale-free networks ${ }^{30}$ in the world around us is explained by this asymmetry characteristic of dynamic logical space, a trace that explicitly differentiates it from those theories of logical space bequeathed to us by the analytical tradition ${ }^{31}$. Scale-free networks are characterized by the presence of hubs, a few nodes with a big number of connections, which guarantees network resilience against random variations.

24. I would like to conclude my notes returning to the beginning: I mentioned that I noticed, in that flight across the Atlantic, that I approached a theory of thought via a route leading to the maximum predominance of the Many (to Gorgias' Configuration). In this way, my demarche

\footnotetext{
28 Or the Leibniz's Quadrants.

29 LEIBNIZ, 1898, §58.

30 BARABÁSI, 2002.

${ }^{31}$ For example: Wittgenstein, 1997.
} 
seemed, at first sight, to set me apart from Meillassoux's path entirely. However, the more we moved apart down these separate roads, the closer we came - since minimally determined thought, thought in which the notes of Many are dominant over those of the One, is precisely that thought in which nothing more is determinate apart from the iteration of the requirement of coherence itself. We can thus see that taken to its extremes, Gorgias' Configuration reverts into Parmenides' one ${ }^{32}$.

It is thus that, in the vicinity of Cusanus' Configuration, the mathematician and the poet shake hands.

Authorized translation by Rodrigo Nunes

\section{Bibliography}

Barabási, A.-L. 2002. Linked. The New Science of Networks. Cambridge: Perseus. Cirne-Lima, C. 2006. Beyond Hegel. A Critical Reconstruction of the Neoplatonic System. Trans. H. L. Hofmann. Accessed November 20, 2017. http://www. carloscirnelima.org.

Dipert, R. R. 1997. The Mathematical Structure of the World: The World as Graph. The Journal of Philosophy, 94, n.7:329-358. https://doi.org/10.5840/ jphil199794738

Feyerabend, P. 1993. Against Method. 3rd ed. London, New York: Verso.

Gabriel, M. 2009. "The Mythological Being of Reflection - As Essay on Hegel, Schelling, and the Contingency of Necessity". In: M. Gabriel/ S. Žižek. Mythology, Madness and Laughter. Subjectivity in German Idealism, 15-94. London/NewYork: Continuum. https://doi.org/10.1017/hgl.2013.19

\footnotetext{
32 This is a possible explanation for the continuous oscillation we find in Meillassoux between a defence of a theory of radical contingency, which unfolds in the vicinity of Gorgias' Configuration, and a theory of almost-pure forms of thought and being, in the vicinity of the Parmenides' Configuration. Meillassoux seems unaware of how these two configurations merge and revert into each other in vicinity of Cusanus' Configuration. Approaching Gorgias' Configuration I am finally, through the phenomenon of reversal, drawing near Parmenides' Configuration; and I will thus be able, in a different moment, to make explicit my divergence of building a theory of almost-pure forms of thought by means of set theory. A more fruitful approach would be, in my view, to develop a theory of almost-pure forms of thought based on graph theory. Cf. Dipert, 1997.
} 
Hegel, G. W. F. 1990. Wissenschaft der Logik [WL]. In E. Moldenhauer \& K. M. Michel, eds. Werke in 20 Bänden. 2nd ed. V. 5-6. Frankfurt am Main: Suhrkamp. Kant, I. 1993. Prolegomena zu einer jeden künftigen Metaphysik [Prol] 7th ed..Hamburg: Meiner.

Kant, I. 1990. Kritik der reinen Vernunft [KrV]. 3rd ed. Hamburg: Meiner.

Leibniz, G. W. 1898. The Monadology and Other Philosophical Writings. Trans. R. Latta. Accessed May 23, 2012. http: //archive.org/ stream/ monadologyotherp oo gott\# page/n5/ mode/2up. https://doi.org/10.5962/bhl.title.27631 Luft, E. 2001. As Sementes da Dúvida. Investigação Crítica dos Fundamentos da Filosofia Hegeliana. São Paulo: Mandarim.

Luft, E. 2010. “Ontologia Deflacionária e Ética Objetiva: Em Busca dos Pressupostos Ontológicos da Teoria do Reconhecimento". Veritas, 55, n. 1: 82-120. https://doi.org/10.15448/1984-6746.2010.1.7324

Luft, E. 2014a. "Dialectic and Network Ontology. The Concept of Reason after Hegel." In H. Ferreiro, T. S. Hoffmann, and A. Bavaresco, eds. LoS Aportes Del Itinerario Intelectual de Kant a Hegel, 946-978. Porto Alegre: Edipucrs/Editora Fi.

Luft, E. 2014b. Notas para uma estética do pensamento“. In Filosofia na PUCRS: 40 anos do Programa de Pós - Graduação em Filosofia, 1: 172-92. Porto Alegre: Editora Fl; Edipucrs.

Luft, E. 2015. "Hegel's Science of Logic as Metalogic." Kritisches Journal 2.0 1: 44-59.

Luft, E. 2017. "Plato or Platonism. A topic in descending dialectic". Veritas, 62 n. 2 (May - August): 407-27. https://doi.org/10.15448/10.15448/19846746.2017.2.27451

McDowell, J. H. 1996. Mind and World. Cambridge: Harvard University Press Meillassoux, Q. 2012. Iteration, Reiteration, Repetition: A Speculative Analysis of the Meaningless Sign Conference. Berlin: Freie Universität Berlin. Accessed November 20, 2017. https://cdn.shopify.com/s/files/1/0069/6232/files/Meillassoux Workshop_Berlin.pdf.

Theunissen, Michael. 1994. Sein Und Schein. Die Kritische Funktion Der Hegelschen Logik. 2nd ed. Frankfurt am Main: Suhrkamp.

Wittgenstein, L. 1997. Tractatus logico-philosophicus. In J. Schulte, ed. Werkausgabe in 8 Bänden. 11th ed. V 1. Frankfurt am Main: Suhrkamp. 


\section{Endereço postal}

Programa de Pós-graduação em Filosofia da PUCRS Av. da Ipiranga, 6681, prédio 5 - Porto Alegre, RS, Brasil - email: eduardo.luft@pucrs.br 